Robert Roche Olivar*

ORCID: 0000-0002-0796-5193

Sandra Rodriguez Gil**

ORCID: 0000-0001-9844-669X

Barcelona, Spain

\title{
Prosociality Inspired by the Charism of the Unity of Chiara Lubich. An Application in the School of Childhood
}

\section{Prospołeczność inspirowana charyzmatem jedności Chiary Lubich. Przykład wykorzystania w przedszkolu}

Summary: This article presents two distinct parts. The first tries to answer the questions: How do spiritual or religious intuitions apply in life? Or, better, how do certain evangelical passages come to pass when they pass through a structuring of

* Dr. Robert Roche Olivar, emeritus professor of psychology in the Faculty of Psychology as well as Director of LIPA (Applied Prosocial Research Laboratory) at de Universitat Autònoma de Barcelona. Web: www.rocherobert.wordpress.com; www.prosocialidad. wordpress.com; www.lipa-net.org. Adress: Campus de Bellaterra, Universitat Autònoma de Barcelona, Postal Code: 08193, Spain; e-mail: robert.roche@uab.cat.

** Sandra Rodríguez Gil, specialist in pre-school education, cooperative learning specialist, director of Laboratori Investigació Prosocial Aplicada. Address: Laboratori Investigació Prosocial Aplicada, Dep. Psicologia Bàsica, Evolutiva y de l'Educació, Universitat Autònoma Barcelona, Postal Code: 08193, Spain; e-mail: sm.rodriguez@movistar.es. 
a system of thought? What application characteristics can a certain charism have when analysed and experimentally applied from a scientific perspective and methodology? In this first part, we present a biographical and professional journey of an academic group that started from a concern and experience of a person, the first author, for about 38 years. This group was trying to develop a theoretical-application model initially originated in the educational field and currently active in various areas of human activity, responding to the spiritual charism of a contemporary woman recognised by an institution as universal by the church. The second part shows one of the last experiences of these applications in the educational field. This experience occurs specifically in the infantile age, which is a crucial stage to mark positive tracks in the development of the personality, as well as positive patterns for the later interpersonal and social relations that employ prosociality and cooperation with a very experimental methodology.

Keywords: prosociality; charism of unity; school of childhood; Applied Prosocial Research Laboratory; Participation Action Research.

Streszczenie: Artykuł składa się z dwóch części. W pierwszej podjęto próbę odpowiedzi na pytania: $w$ jaki sposób duchowe lub religijne intuicje znajdują zastosowanie w życiu? Lub bardziej, co staje się z konkretnymi fragmentami ewangelicznymi, gdy przechodzą przez strukturę systemu myślenia? Jakie charakterystyczne cechy może uzyskać określony charyzmat, gdy analizuje się go i eksperymentalnie wprowadza w życie z naukowej perspektywy i metodologii? W pierwszej części przedstawiamy biograficzną i zawodową podróż grupy akademickiej, która rozpoczęła się od troski i doświadczenia osoby, pierwszego autora, około 38 lat wcześniej. Grupa ta starała się opracować model teoretyczno-aplikacyjny, początkowo osadzony w dziedzinie edukacji, a obecnie wprowadzany w różnych obszarach ludzkiej aktywności, odpowiadając na duchowy charyzmat współczesnej kobiety uznany za uniwersalny przez Kościół. Druga część prezentuje jedno z ostatnich doświadczeń owych aplikacji w dziedzinę edukacji. To doświadczenie odnosi się do wieku niemowlęcego, który jest kluczowym momentem w kształtowaniu pozytywnych rysów w rozwoju osobowości, jak również w budowaniu pozytywnych wzorców dla późniejszych relacji interpersonalnych i społecznych, łącząc prospołeczność i współpracę z bardzo eksperymentalną metodologią.

Słowa kluczowe: prospołeczność; charyzmat jedności; przedszkole; badania w działaniu; Laboratorium Stosowanych Badań Prospołecznych. 
In 1981 a study, research and application experience was born at the Universitat Autònoma de Barcelona, about the word and the concept of prosociality, which over 37 years has impregnated my life, personal, family and professional.

This word referred to a concept related to the "prosocial behaviours" that, in those years, Dr. Paul Mussen and Dr. Nancy Eisenberg used in one of the first publications in which the term "prosocial behaviours" appeared".

At that time (1981), as a professor of psychology at the Universitat Autònoma de Barcelona, I was looking for a topic and a line of research that could reconcile my work profile rather than from a clinical perspective of pathologies, always referring to the positive development of the human potential. I realised that in the spirituality of the Chiara Lubich ${ }^{2}$ charism of Unity, I already had the dimensions I was looking for to study and apply to personal, interpersonal and professional life and thus both verify and contrast its meaning and functionality for the human being and for social relations.

Among the elements named were concrete universal love to every human beings, reciprocity in that mutual esteem and unity in diversity; unity that in the Christian charism manifests the presence of Jesus in the middle of two or more people. Here I asked myself what its manifestation and concrete application in psychology would be: I intuited a positive revolution for interpersonal and social relationships.

I wanted to penetrate the deep dimensions of each of these elements to make them visible, tangible and concrete, discovering and checking the possible effects and the consequences of them. Immediately, I realised that my methodology could not be devoted to studying a phenomenon from the outside. I wanted to ensure an integral research that was obtained from the study, the theory, but also from life and experience. My research coincided with the PAR methodology (Participation-Action-Research) which, at that time, is still little understood and used. In that period began the scientific accreditation of qualitative methodology.

In 1983, at the Palaeur in Rome, 12,000 people gathered to formalise the launch of the New Humanity movement. It was an important moment for

${ }^{1}$ Paul Musse, Nancy Eisenberg, The Roots of Caring, Sharing, and Helping: The Development of Pro-Social Behaviour in Children (San Francisco: W. H. Freeman, Nation at Risk, 1977).

2 Doctoral honoris causa in Pedagogy ad University of America in Washington: Chiara Lubich, "Lezione per la laurea honoris causa in Pedagogia, Washington, 10 novembre 2000", Nuova Umanità 135-136 (2001/3-4): 341-352. 
the take-off of what, over the years, would be the LIPA at the Autonomous University of Barcelona ${ }^{3}$.

In those first years and after a trip to San Francisco on the occasion of a scholarship grant, and an invitation from Prof. Mussen, I acquired a pioneering experience in some schools of San Francisco that focused their work on teaching prosocial issues within a Development Project research project. This project guided our first investigations applied to the educational field in Catalonia, and the first programme in schools in the periphery of Barcelona, requested and supported by the government of the Generalitat de Catalunya, which confirmed the educational field as the pioneer in our application of prosociality (the consolidated term in Castilian and Catalan is substantive while in the USA it had still not passed the adjective).

Later, LIPA contributed in several languages to move from the prosocial adjective, to the substantive prosociality and now to the verb "to prosocialise", coinciding with the elaboration of a definition that we needed to characterise what we considered innovative in our dynamic work as a result of both academic theory and an application in life and in the relationships between people close to LIPA, and those who already constituted the own group. Thus, prosociality became the centre and the motor of the study while maintaining the spirit of LIPA at the same time.

\section{Definition and categories and inventories}

\section{Definition}

In our LIPA team (Applied Prosocial Research Laboratory), at a first level of definition, even on a theoretical level, we understand prosocial behaviours as

Those behaviours that, without the search for extrinsic or material rewards, favour other people or groups according to their criteria, or objectively positive social goals, increasing the probability of generating a positive reciprocity of quality and solidarity in consequent interpersonal or social relationships, safe-

${ }^{3}$ LIPA: Laboratorio de Investigación Prosocial Aplicada of the Universidad Autónoma of Barcelona. LIPA is a multidisciplinary and international team formed by some professors of the UAB and several external specialists. 
guarding the identity, autonomy, creativity and initiative of the individuals or groups involved ${ }^{4}$.

This definition, has already been extensively developed in previous publications ${ }^{5}$ and has recently been adapted in an unpublished manuscript $t^{6}$. This definition emphasises a fundamental aspect unlike other definitions; the fundamental criterion that constitutes a prosocial action is the criterion of the receiver, that is to say that he approves and is satisfied with it.

A prosocial action, we could synthesise, is one that effectively benefits the other, just as he wants to be benefitted. This is in contrast with a conception of "help" actions which do not include in the "prosocial" model the circumstances, needs, identity and culture of the recipient.

Incorporating the reality of the other in the precise definition of prosociality avoids the risk of tolerating as prosocial actions that more than benefit, even harm the other. For example, doing a favour with good intention that the recipient does not appreciate because it simply has not helped him; or perhaps it generates dependency relationships; or unintentionally, with the desire to help on the part of the author and to make the other feel undervalued.

The prosociality from this optics is almost contagious, being easily imitable and facilitating learning. That is to say, the prosocial action is a very simple action, within the reach of anyone and therefore it is an easily identifiable and facilitating field of learning.

All prosocial action has these elements:

- some degree of creativity;

- some assertiveness;

${ }^{4}$ Robert Roche, Hacia una teoria de prosocialidad Lipa (Barcelona: Universidad Autonoma de Barcelona, 2014), 19. Manuscrito no publicado.

${ }^{5}$ Robert Roche, "Violencia y Prosocialidad: un programa para y descondicionamiento frente a la violencia en la imagen y para la educación de los comportamientos prosociales". in: ¿Que Miras? (Valencia: Publicaciones de la Generalitat Valenciana, 1991), 291-313; Robert Roche, Psicología y Educación para la prosocialidad (Buenos Aires: Ciudad Nueva, 1997); Robert Roche, "L'educazione alla prosocialità come ottimizzatrice della salute mentale e della à nelle relazioni sociali”, Nuova Umanità 21/121 (1999): 29-48; Robert Roche, Inteligencia prosocial: educación de las emociones y valores (Cataluña: Servei de Publicacions Universitat Autònoma de Barcelona, 2004); Robert Roche, Educacion Prosocial de las emociones, valores y actitudes positivas para adolescentes en entornos familiares y escolares (Barcelona: Blumes, 1998); Robert Roche, Prosocialidad: Nuevos desafios. Metodologías y pautas para una optimización creativa del entorno (Buenos Aires: Ciudad Nueva, 2010).

${ }^{6}$ Roche, Hacia, 19. 
- a certain cost, important in the personal feeling of ability and proactivity;

- some positive result or benefit;

- some certainty about the functionality of the action;

- certain meaning feedback;

- certain positive reinforcement of beliefs regarding goodness and positive human relationships;

- a high probability of achievement and success, which increases the

- probability of repetition.

Perhaps they are of the order of human behaviours, being more common and accessible to every person, with more possibilities of achievement or success and more accessible for its execution in interpersonal time and space.

\section{Classes or categories of prosociality}

We have identified 10 classes or categories of prosocial LIPA actions. These are: 1) physical assistance; 2) taking care; 3) giving and sharing; 4) verbal assistance; 5) verbal consolation; 6) confirmation and positive evaluation of the other; 7) close listening; 8) empathy; 9) solidarity; 10) positive presence and unity.

\section{The Prosocial Inventories}

A LIPA Prosociality Inventory is "A list of operative prosocial behaviours, according to the LIPA categories, that are more desirable and possible in a specific context or scope, prepared by a researcher, based on the criteria of all the people involved in the aforementioned area"7. To reach this level of concretion and operationalisation, a procedure is proposed applying the Participatory Action Research to define a list of desirable and feasible prosocial behaviours in any system, according to the needs and perceptions of the actors specifically involved in each context ${ }^{8}$.

The methodology of the prosocial inventories in context has proven to be a useful tool for the design of prosocial optimisation plans for every ambit. It is also an excellent tool for the diagnosis and evaluation of the levels of prosociality of groups or work teams. For example: departments of an or-

\footnotetext{
${ }^{7}$ Robert Roche, L'intelligenza prosociale (Trento: Erikson, 2002).

${ }^{8}$ Roche, Prosocialidad.
} 
ganisation, a company, a college of teachers, a neighbourhood communities, sports clubs, supermarkets, or discos.

\section{Multipliers origins of the experience}

In 1994, an event occurred that gave an unexpected dimension to our work. At that time, the political regime in the old Czechoslovakia had changed and this state had split into two. The rulers of both tried to find a humanistic subject that would replace the one corresponding to the study of Marxism with the possibility of combining the experiences of teachers, both of whom had taught Marxist philosophy with those of other philosophies, for example Christian. Thus, in Slovakia, they decided, with the advice of government councillor Ladis Lencz, to set up a matter of Ethics, acceptable for all orientations and applicable in all grades of compulsory education. Our texts on prosociality were included in the first texts of a call Eticka Vichova $a^{9}$. We were then called by the vice-ministry to contribute in the formation of the first trainers (1994-1997).

Today, after almost 25 years, there are already more than 3000 teachers who have been trained in this project and thousands of students; there are also 5 chairs in five faculties in Slovakia, with hundreds of specialised students. Furthermore, in the Czech Republic we have collaborated in different formations and courses for some degrees, in Prague (13th-16th November 2003) and Kromeriz. There are doctoral theses on prosocial education in the Czech Republic.

In this respect, it is essential to move forward (in addition to the need to continue researching) in the dissemination and transfer of pioneering and successful experiences, which have also proved to be innovative, sustainable and transferable to other contexts. One example of this could be school and civic education programme based on prosociality, incorporated into the teaching of ethics for the Slovak whole system educational programme ${ }^{10}$.

In all this development, our epistolary contact with Chiara Lubich was frequent. She always responded to our letters or communications of the results and evidences of which she gave us words of praise and encouragement.

9 Ladislav Lencz, "The Slovak Ethical Education Project", Cambridge Journal of Education 3/24 (1994): 443-451; Robert Roche, Eticka vychova (Bratislava: Orbis Pictus Istropolitana, 1992).

${ }^{10}$ Lencz, "The Slovak"; Roche, Eticka vychova. 
LIPA has always been a centre open to dialogue with all convictions. In fact, since 2003 the centre director has ensured that it is constituted of people linked to the Christian conception and other different views. For me personally, I have always responded when I have been asked that the personal inspiration for this experience has been the hypothesis approach and the search, contrast and verification of them from a scientific and academic translation of the spirituality of Chiara Lubich.

From the beginning, working to build a theoretical model of prosociality in many areas could scientifically demonstrate that its systematic and concrete programme could be effective solutions and responses to the great problems of today's man. Demonstrated by its meaning and functionality and even effectiveness without needing to cite a provenance, try to translate and embody the charism of the Unity in a theoretical way but at the same time concrete, specific and even systematic in the scientific and academic field.

\section{LIPA currently}

LIPA is a centre for research, training, advice and dissemination of prosociality applied to interpersonal, group and social relationships, which guides their professional and personal projects with a shared vision, shared and applied in the lifestyle, in the work of the team and in the relationship established with the local experts with whom they work.

The LIPA team bases all its interventions on the epistemological framework of the Participatory Action Research and on the values represented by prosociality (dignity of the person, communication of quality and esteem and love for all people). LIPA operates in a scientific, academic, social and business framework through applied research, training, intervention projects, scientific and informative publications.

It has been researching and applying optimisation programmes for nearly thirty years on the fundamental variables that affect the development of the communication process, especially those that can be critical for an efficient and satisfactory communication, which is called Prosocial Quality Communication ${ }^{11}$. Through the transfer of knowledge in the course of all the

${ }^{11}$ Gloria Pilar Escotorín Soza, Comunicación interpersonal de calidad prosocial: hacia una definición del concepto y síntesis teórica actualizada del modelo aplicable a díadas en contextos organizacionales (Bellaterra: Universidad Autónoma de Barcelona, 2008); Robert Roche, "Comunicación de calidad en la pareja y en las relaciones interpersonales", Familia 
developed projects, LIPA has shown that the promotion of a Prosocial Quality Communication through training spaces and with specialised methodology directly affects the satisfaction, success or adjustment of relationships interpersonal and within organisations ${ }^{12}$.

In the last 10 years, we have been interested in extending proven intervention methodologies to enlarge settings to adult contexts of high complexity: hospitals, prisons, businesses organisations, neighbourhoods, politics and universities, among others.

As a team, together with universities in Europe and Latin America and professionals from various disciplines, we have participated in some $15 \mathrm{Eu}-$ ropean projects on applied prosociality transfer, offering methodologies to intervene in social problems such as school dropouts (MOST Project, 2011), transfer of prosociality in the field of healthcare (CHANGE Project, 2010). We have also been involved in the tourism business sector (Project Train to Change, 2013), or in university education to improve equity indices in access to the labour market in Latin America (Project SPRING, 2012).

Currently, research on prosociality has gained a place not only in the field of psychology, but also in economics, health, education, politics and the neurosciences, among others ${ }^{13}$. Interest in investigating the issue is increasing as a phenomenon or substantive: prosociality ${ }^{14}$ as a verb, to account

y Sociedad 1 (1994): 363-367; Robert Roche, Psicología de la Pareja y de la Familia Analisis y Optimización (Bellaterra: Servei de Publicacions Universitat Autònoma de Barcelona, 2006); Robert Roche, Esther Arozarena, "Algunas dimensiones de la comunicación de calidad en la pareja”, Actas de las IX Jornadas Españolas de Terapia Familiar 18 (1988): 425-445; Robert Roche, Reinaldo Martínez-Fernández, "Efectos de un programa de entrenameinto prosocial en la comunicación de pareja", Revista de Tarapia Sexual y de Pareja 24 (2006): 30-50.

12 Robert Roche, Prosocialidad; Pilar Escotorín Soza, Robert Roche, Cómo y por qué prosocializar la atención sanitaria: reflexiones, desafios y propuestas. Conclusiones del Proyecto Europeo CHANGE (La Garriga: Fundación Martì L'Humà, 2011).

${ }^{13}$ Gloria Pilar Escotorín Soza, Prosocial Communication Inquiry in collaboration with gerontology health professionals. Consulta sobre comunicación prosocial con profesionales socio-sanitarios del ámbito gerontológico (Universidad Autonoma de Barcelona. Bellaterra: 2013). Tesis doctoral no published.

${ }^{14}$ Robert Roche, "Violencia", 291-313; Robert Roche, Psicología y Educación para la prosocialidad (Barcelona: Universitat Autònoma de Barcelona, 1995); Bernadette P. Luengo Kanacri, Concetta Pastorelli, Nancy Eisenberg, Antonio Zuffianò, Gian Vittorio Caprara, "The Development of Prosociality from Adolescence to Early Adulthood: The Role of Effortful Control", Journal of Personality and Social Psychology 3/81 (2013): 302-312; Gian Vittorio Caprara, Guido Alessandri, Nancy Eisenberg, "Prosociality: The Contribution of Traits, Values, and Self-Efficacy Beliefs", Journal of Personality and Social Psychology 6/102 (2012): 1289-1303. 
for an intervention methodology - to prosocialise ${ }^{15}$. Above all, most publications are focused on the "prosocial" as an attribute or adjective which involves prosocial behaviour, prosocial communication, prosocial thinking, prosocial intelligence, prosocial empathy, prosocial action.

It is significant to note that LIPA has promoted and directed several doctoral theses. Among them, one is dedicated to Prosocial Communication Quality $^{16}$ and two aimed at Prosocial Leadership ${ }^{17}$, as an alternative to transactional and transformational leadership.

In the diffusion and multiplication of the theoretical application model of the LIPA Prosociality, we can indicate the courses, seminars, workshops, programmes conducted or directed or instructed in more than 20 countries. These include Italy, Spain, Slovakia, Czech Republic, Croatia, Macedonia, Ukraine, Lithuania, Germany, Romania, Austria, Argentina, Peru, Cuba, Chile, Brazil, Mexico, Colombia, Bolivia, Ecuador and Venezuela.

The concept of prosociality has positioned itself in scientific research as a long-lasting topic, while the term "prosocial action" is beginning to be already well known and even employed by people in general. These terms are also connected as keywords in the most current search engines, such as Google.

However, the paradox is that the scientific community has demonstrated the benefits of prosocial behaviours. Yet there is still a great difference between what studies have already shown to be beneficial for social practice and what in the culture of organisations is often implemented or lived.

\section{PROT (Prosocial Optimisation Theory)}

In recent years, we have been trying to collect the differentiating characteristics of the study and the experiential and professional application of prosociality in LIPA. The name with which we define this model is the Theory of Prosocial Optimisation (PROT).

15 Escotorín Soza, Roche, Cómo y por qué.

${ }^{16}$ Escotorín Soza, Prosocial Communication.

17 Maria Carme Cirera Amores, Estudio cualitativo del liderazgo prosocial: El Proyecto SPRING (Bellaterra: Universidad Autónoma de Barcelona, 2015); Ana Esther Bedoya Rodriquez, Del liderazgo transformacional al liderazgo prosocial: Evidencias obtenidas en la Dirección de organizaciones sanitarias catalanas (Bellaterra: Universidad Autónoma de Barcelona, 2015). 
The title assigned to the theory answers, shows and evidences the name of a subject of the career of the Faculty of Psychology of the Autonomous University of Barcelona for more than 17 years.

It is based on the work of 10 years of "incubation" from the Anglo-Saxon standard definition (since 1982) and another 22 (until 2014) until one of the most recent academic work, the thesis of one of the authors, Soza Escotorin ${ }^{18}$. These are periods in which an original and own concept has been delimited, based on research and also on a methodology used in teaching in the Psychology career of the Autonomous University of Barcelona from 1994 to 2000 (Optimisation of Social Development: Learning Prosocial Behaviours) and from 2000 to 2011 (Prosocial Optimisation). Subjects for undergraduate and doctoral students in psychology studies, who have known the concept, have appreciated it and we know that many of them have used it in their work, therefore it is disseminated throughout all of our country.

Therefore, since 1994, they have uninterruptedly completed an average of approximately 65 students per year that total about 1300 (today, most of them qualified psychologists).

In the theoretical and practical classes of the subject, and following the methodology of the Participatory Action Research, the theory has been investigated, application and intervention practices have been carried out with innovative techniques, in which the students became true living laboratories as agents and prosocial operators, both in personal and professional spheres, elaborating intervention projects in very defined contexts.

PROT is configured as a theoretical-application model derived from a definition of prosociality developed in three levels: a first conceptual or theoretical level (what is understood by prosociality ${ }^{19}$ ) a second level that limits this definition in ten operational categories ${ }^{20}$ and a third level, which precisely and with limited methodology, defines and adapts the ten categories for each context in a differentiated manner ${ }^{21}$. In the present article, these three levels are also defined as an intervention methodology

This model has been articulated in 8 dimensions:

1. Optimisation

2. Prosociality centred in the receiver and his context

3. Reciprocity and systemic horizontality and circularity

\footnotetext{
${ }^{18}$ Escotorín Soza, Prosocial Communication.

19 Roche, Eticka vychova; Roche, Prosocialidad.

20 Roche, Eticka vychova; Roche, Prosocialidad.

${ }^{21}$ Escotorín Soza, Roche, Cómo y por qué.
} 
4. Empathy and Unity

5. Responsibility and engagement and agency

6. Participation Action Research

7. Operative categorisation of prosocial actions

8. Inventories of prosocial actions by receivers-beneficiaries

\section{An application in the school of childhood}

\section{A crucial moment for socialisation}

The questions that the educator or teacher could ask are, when does the process of socialisation between peers begin and what is the best way to deal with it. The intriguing question would be which aspects of this age group are most affected in the healthy and efficient development of a person, as well as in the development of interrelations between healthy people and cooperatives, therefore contributing to accomplishing and coming closer to a utopian vision of a more peaceful and harmonious society.

The new methodologies affect the child as a protagonist of their own learning, in the education in values, in the development of critical and in creative thinking, using play as a source of learning and learning projects as a globalised and interdisciplinary method, etc. Undoubtedly, all of these strong ideas change the sense and direction of education, but what if, in the social value they promote, we added the value of "my other self"? In this line, the Prosocial Model seems to balance the scales.

On the other hand, these methodologies and educational models start with older children, maybe influenced by the great lack of effective methods. However, it is at two years of age when the curiosity of their peers naturally arises in children. We find ourselves at the first stage; that is, at the beginning of the horizontal socialisation processes, in which they have not yet acquired a significant number of skills ${ }^{22}$.

This is, therefore, where the learning of prosocial behaviours would be of great value in the building of the personality and acquiring a preventive character, like a learning model for a more harmonious coexistence ${ }^{23}$. Hence,

${ }^{22}$ Ellen McGinnis, Arnold Goldstein, "Programa de Habilidades para la Infancia Temprana", http://www.oei.es/historico/inicial/articulos/habilidades_infancia.pdf [dostęp: 20.02.2018].

${ }^{23}$ Roche, Psicología y Educación. 
a case is presented below as a sample of the research-intervention-research work (Participation-Action-Research) that reflects a class where an investigation has been carried out with a group of fifteen children that are two years of age.

\section{Case of J.G.}

J.G. is a child who has a great linguistic ability. At his young age, he builds complete sentences without committing grammatical errors. He uses articles and conjugates verbs correctly. He can express wishes, feelings and thoughts. He also understands and relates several messages, demonstrating a high level of understanding, internalisation and assimilation that is demonstrated in daily activities. He also has a great vision of the area around him, where he plays with different materials and builds simple structures that he seems to have planned in his mind. He can also easily handle numbers and amounts and is able to recognize words that have been taught during the teaching programme. At a social level, he works well. He attends and plays with his classmates, although he likes doing it better by himself. He communicates with them, responds to questions and participates in the spontaneous dialogues that arise between them. He is a child who is confident in carrying out the routines but is not really flexible to change.

Problems that have arisen:

- He doesn't allow other children to participate in their game.

- He collects a lot of material to start playing with and keeps it so that nobody takes it.

- He responds by crying and chasing the other child who has taken one of his toys to take it back.

Objectives to achieve:

- To interact with other children in moments of free play.

- To share the materials.

- To use verbal language as a way to solve problems.

Hypothesis:

- Self-centeredness prevents children from sharing easily (H1).

- Cooperative learning favours the modelling phase (H2).

- The collaboration in different contexts (family and school) favours a more consolidated learning in social behaviours (H3).

Variables:

- Reactions to crying and tantrums (V1). 
- Allow other children to participate at playtime (V2).

- Share the toys (V3).

Methods to implement the prosocial ability to share:

- Learning by Observation: this will be used as a model for learning, what the teacher and the other children do or say. To help with this learning process, we will offer models of correct behaviour and we will put together the results, generating pleasant situations to help with the imitation to the others.

- Approach technique: the objective will be reached gradually, so that the desirable behaviour can be learnt step by step. For this, we will decompose the objective and teach the children to reinforce positive behaviours to him.

Family and school coordination:

To encourage effectiveness in the learning process, the participation of the family is requested. Here, the parents will be asked for support in the intervention programme, underlining the importance of their collaboration and implementing the programme with the family's concerns and their ideas.

Development of the learning process:

The teaching-learning process will be developed with 4 basic techniques:

- Modelling: the child will achieve this by observing his teachers and classmates' behaviour. This stage will be developed by trying to reach the overlearning behaviour until it becomes natural and spontaneous.

- Role plays: through the representation of real situations, the child will adopt more significant behaviours and attitudes to the skill that is being worked on.

- Feedback: will be based on social reinforcements such as praise and approval. The first experiences will be reinforced through the technique "point's contract". The goal will be to make the material reinforcement disappear and maintain the social reinforcement.

- Transfer: Behavioural learning will begin in the classroom. Depending on the student's response, similar situations to those experienced in the classroom will be created in another environment in the school and family context.

\section{Steps to teach the social skill "to share"}

An interview is arranged with J.G.'s family in order to inform them of the behaviour modification programme and to establish a joint action plan 
that reinforces the work at school. At school, the plan starts with the "Circle of friends", a cooperative activity that has been running in the classroom for several weeks. In the circle we will emphasise that sometimes J.G. gets angry and that we will help him always to be happy by using the phrase "J., it doesn't matter. Let's share everything. One for you, one for me".

\section{First week}

A plan will be developed for the children to play together sharing the material:

- For this, the children will work in the cooperative base groups already constituted in the classroom, giving each group a specific material.

- The teacher will focus on the team in which J.G. is in and will act as the other children do, thus causing their behaviour to be modified. Once this happens, the teacher will show the desired behaviour and act as a model of learning.

- As the week progresses, the teacher will involve the members of the J.G.'s team, first reinforcing good behaviours and then, as his tutors encourage learning, using the other children as models.

- At this time, the family is asked to carry out the same action. In an interview, with the parents the guidelines of the game that will be carried out at home are established. The father and the mother will be the playmates of J.G. The key will be to act like the other children, not giving attention to what J.G. wants to do, but to use the material freely to make whatever one wants.

- The material will be placed in the centre so that everyone can have access to it. In this way we will create the awareness that the material belongs to everyone. The key is, "take one at a time, only what we need, to the others can play as well".

\section{Second week}

- We will change the material and repeat the process until J.G. participates in the sharing activity, avoiding attitudes of ownership and custody of the material.

- In the end, we will create role-playing games in which we will create real situations in the groups that show moments of sharing. This 
requires that the teacher is observant, so that systematised observation tables will be used for data collection (See Annex).

\section{Third week}

- The transfer of acquired learning will be realised and situations similar to those experienced in the classroom will be created.

- At home, it will be recommended that the family invite some friends, so that J.G. can share some of his toys (of which he decides.) It is important that this decision is made before the visit and that he, with the help of his parents, prepares and presents the material to his friend who comes to his home.

- Meanwhile, at school J.G will be invited to carry out the cooperative technique "La suitcase", in which he will bring and show his companions his favourite toys, with the intention of sharing them. This technique has been carried out by other children and J.G. has had the opportunity to see how they agree to share what they bring from home; therefore, there has been a previous modelling experience.

In the ANNEXES, the process presented here can be visualised in detail. The first table presents the data that preceded the investigation and then below the procedure carried out in a systematic and methodical way is presented.

\section{Conclusions}

The background of the investigation is with a heterogeneous group of two-year-old children. Among them is J.G., a child who has a great ability to communicate but few social skills that are displayed during the coexistence in the classroom with the rest of the children.

At two years of age, curiosity about other children arises spontaneously. This investigation has been made because of the need to act in the classroom, due to the disruptive behaviours that arise. The objective is to reveal that the methodologies that are shown as foremost must begin straight away; in this case, the horizontal social relations. Under the philosophy of Cooperative Learning and education towards Prosociality, a hypothesis and variables are established that aim to give an importance to this early vision of social education. 
The formulated variables show an evolution throughout the process that responds to the meticulous gradation of the objectives to be achieved. The Approach Technique has been a key to the achievement of the objectives. In this case, the variable "Reactions to crying and tantrums", which verifies the hypothesis of a marked egocentrism in this age, has required a constant supervision from the teacher, establishing measured guidelines for "Time out, substitution of negative behaviours with short sentences that resolve the conflict, etc". "The Modelling Phase" is based on the support of Cooperative Learning. Everything that has been experienced in a group and in the interaction with the other children so acquires an emotional value that consolidates learning in favour of the appearance of new behaviours that have subsequently been naturally transferred in other contexts. The variable "Allowing the participation of other children to play" was discovered under this philosophy of living and building together new experiences and during the investigation, there was a constant progression in the child.

The security provided in the context of the classroom, thanks to the meticulous work with the habits and routines that have been carried out, has turned the group work into a guided training, in which J.G. has been able gradually to experience a greater number of achievements that have been reflected in the child's self-esteem and self-concept.

Prosocial behaviours are a world to discover for the children at such an early age. Through role-playing games, students have learnt to substitute certain impulses that generate a conflict for more positive phrases and attitudes. Here, role-playing games have been carried out in pairs. Two children is the minimum unit of social learning. This training has favoured the consolidation of these new experiences, which have spontaneously appeared during free play, demonstrating the first signs of reciprocity.

Finally, the family's accompaniment and involvement has been fundamental in the process. The family is the natural learning environment for the child, while the school offers the opportunity to extend this learning by promoting the interaction between the children. The complicity between both contexts has consolidated the appearance of prosocial behaviours outside the walls of the school; first within the family circle to guarantee the safety and self-esteem of the child during the process, later with a friend and finally in the park. Again, the gradation of the experiences is fundamental in the learning process.

Therefore, the hypotheses raised in the investigation are fulfilled in a concatenated form. The frustration that causes the child's lack of under- 
standing of other perspectives different from his own, is something natural. A suitable education project has helped J.G. to change his attitude and to be more flexible to change. The support of the other children has been indispensable. When learning is carried out from a single vertical perspective (adult-child), it loses the spontaneity provided by the child's natural context: the other children.

Cooperative Learning offers successful techniques forming the basis of learning based on modelling. Role plays, in pairs, have favoured the learning of prosocial behaviours that later appeared naturally in the children's free play, so demonstrating the first signs of reciprocity. The shared education between family and the school has been a fundamental piece in the consolidation of the behaviours. In early age learning, it is based on the experiences of everyday life. In order to get the child to transfer the new actions in different situations, the collaboration of the family has been fundamental.

It is interesting to note that although the investigation has focused on just one student, the rest of the group has benefited from it. This was shown in the comments made by some mothers of the group who, without knowing the existence of the plan, asked if this skill was being worked on, as their children did it at home and in the park. Once again, it is shown that a learning process based on interaction and feedback between the children has a greater scope than that which is only done vertically.

There are several investigations that we have conducted with groups of children of an early age working on other skills. All of them are based on Cooperative Learning and Prosociality Education as the binomial of successful learning at an early age. Orienting education towards the person and relationships is what undoubtedly constitutes a true innovation in today's school.

The implementation of these educational models in the classroom contributes to the creation of more positive environments, which helps the children to learn to be aware of others using their own initiative. The level of learning at a cognitive level in the classroom is greater because it grows around the emotions generated by social exchange. The self-esteem of the children grows because they feel useful when they can help out their classmates and a reciprocity arises that develops positive attitudes around the children and in their educational performance. 


\section{Annex}

Chart 1: Backgrounds

\begin{tabular}{|l|l|l|l|l|l|}
\hline & \multicolumn{1}{|c|}{ Where } & \multicolumn{1}{|c|}{ How } & \multicolumn{1}{|c|}{ Why } & \multicolumn{1}{|c|}{ When } & Material \\
\hline $\begin{array}{l}\text { Crying and } \\
\text { screaming }\end{array}$ & $\begin{array}{l}\text { in the } \\
\text { classroom } \\
\text { and } \\
\text { playground }\end{array}$ & $\begin{array}{l}\text { chase another } \\
\text { child }\end{array}$ & $\begin{array}{l}\text { they took } \\
\text { away a toy }\end{array}$ & $\begin{array}{l}\text { during the } \\
\text { free play } \\
\text { time }\end{array}$ & $\begin{array}{l}\text { logical } \\
\text { blocks }\end{array}$ \\
\hline Biting & $\begin{array}{l}\text { in the } \\
\text { classroom }\end{array}$ & impulsively & $\begin{array}{l}\text { he wanted } \\
\text { the toys } \\
\text { from the } \\
\text { other } \\
\text { children }\end{array}$ & $\begin{array}{l}\text { they shared } \\
\text { a single } \\
\text { material }\end{array}$ & $\begin{array}{l}\text { coloured } \\
\text { skewers }\end{array}$ \\
\hline $\begin{array}{l}\text { Throwing } \\
\text { the toys to } \\
\text { the ground }\end{array}$ & $\begin{array}{l}\text { in the } \\
\text { classroom }\end{array}$ & $\begin{array}{l}\text { sharply } \\
\text { the teacher } \\
\text { told him that } \\
\text { he should } \\
\text { let his } \\
\text { classmates } \\
\text { take the toys }\end{array}$ & $\begin{array}{l}\text { they could } \\
\text { take one of } \\
\text { materials } \\
\text { freely }\end{array}$ & stories \\
\hline $\begin{array}{l}\text { Finding } \\
\text { another toy } \\
\text { to share and } \\
\text { keeps the } \\
\text { ones he has }\end{array}$ & $\begin{array}{l}\text { in the } \\
\text { classroom } \\
\text { and } \\
\text { playground }\end{array}$ & $\begin{array}{l}\text { pland conciliatory } \\
\text { with the child } \\
\text { who wants } \\
\text { the toy }\end{array}$ & $\begin{array}{l}\text { a friend } \\
\text { wanted one } \\
\text { of the toys } \\
\text { he was using }\end{array}$ & he is calm & stories \\
\hline
\end{tabular}

Chart 2: Hypothesis-Variables

\begin{tabular}{|c|c|c|c|}
\hline & HYPOTHESIS & & VARIABLES \\
\hline H1 & $\begin{array}{l}\text { Self-centeredness prevents children } \\
\text { from sharing easily }\end{array}$ & V1 & Reactions of crying and tantrums \\
\hline H2 & $\begin{array}{l}\text { Cooperative learning favours } \\
\text { the modelling phase }\end{array}$ & $\mathbf{V} 2$ & $\begin{array}{l}\text { Allow other children to participate } \\
\text { in the game }\end{array}$ \\
\hline H3 & $\begin{array}{l}\text { Collaboration in different contexts } \\
\text { (family and school) favours a more } \\
\text { consolidated learning of social } \\
\text { behaviours (H3) }\end{array}$ & $\mathbf{V} 2$ & Share his toys \\
\hline
\end{tabular}


Chart 3: $1^{\text {st }}$ Week

\section{MONDAY}

SITUATION: During the planned activities J.G. is calm and shares the material, which leads us to focus our attention on the activities that present a novelty for him. During this week, we will observe his reactions when he plays supermarket games in different environments and with different materials.

Empty boxes of food, bags and boxes are presented to play freely with. J.G. takes a bag to go shopping. The bag is large and he is able to put more and more things in it, taking material from the other children. When the other children fight for the material, he falls to the ground crying and screaming. The teacher doesn't have to intervene. He gets up alone and goes to the bathroom to cry (this modification of behaviour has been worked on before), when he finishes, he returns but continues with the same behaviour, although less impulsive. The situation is repeated several times.

He plays along with the other children, but there is clear evidence of the game in parallel. He doesn't speak and he throws himself on top of the material to hoard and have control of the game. The teacher tries to intervene to correct his position. He corrects it but loses it immediately to control the game and the material again.

Can't see any intention to share.

\section{TUESDAY}

SITUATION: A trip to a sports centre where we will spend a short time with the players of a professional basketball team. J.G.'s mother goes on the trip.

When the basketball team take out the balls, there isn't one for each child and J.G. spends all his time running behind the other children crying and screaming to get a ball. The mother stops him and gives him long explanations that J.G. doesn't take any notice of as they don't solve his problem.

He doesn't allow the other children to play with him. We make a dynamic activity in which many children, parents and teachers sit in a circle and play with a single ball. The game is to pass the ball to another person whilst saying our name out loud. J.G. doesn't want to participate.

Can't see any intention to share.

\section{WEDNESDAY}

SITUATION: The children are presented with flash cards with images of food on them. Everyone can play with them freely. There is a sufficient number of cards so that each child can have a group of 4 or 5 cards.

J.G. wants to take all the cards to group them together and have a big pile. When the other children go to pick up cards on the floor, he reacts by screaming and crying, pushing and making a move to bite them.

The teacher acts and explains that he has a lot of cards and that he can give some to the other children. J.G. throws all his cards on the floor and starts screaming and crying. The teacher reminds him „Go to the bathroom to cry, come to the classroom to play". 
J.G. goes to the bathroom to cry and after several seconds he returns calmly to the classroom. When he faces the same situation, his reaction is the same, but a greater control of impulsivity is perceived. This time he doesn't go to bite anyone. After a second visit to the bathroom, which he does without the need for the teacher to remind him, J.G. joins in the activity, without crying and plays quietly.

When J.G. joins in the activity without crying, a conversation begins between him and another child. Although his attitude still indicates his intention to hoard all the material, when the other child says, ,You have to share”, he agrees, laughs and starts a quiet game between them.

It can be seen that there is an intention to share after overcoming behaviours of frustration. In the conversation that arises between him and the other child, we can hear phrases such as „We have to share”, „One for you, one for me”, „Look, this is a pear, do you like it?"

\section{THURSDAY}

SITUATION: The classroom is set up, different from usual, with the theme that we are working on (the supermarket).

J.G. enters excitedly in the classroom and plays, taking the prepared material and then letting it go. After 10 minutes he goes to a small kitchen where he starts to make something to eat. The other children approach and he ignores them. When one of them gets too close (to share the same kitchen window), J.G. pushes him and starts screaming and crying throwing himself to the ground. The teacher explains that the two can fit and can play together. His response is to throw himself to the ground and start screaming. We remind him "He has to cry in the bathroom and play in the classroom". After spending a short time in the bathroom, he returns to the classroom and plays without crying.

The time that J.G. is in the bathroom is longer this time. He comes out quietly and starts the game accepting that there is another child in the kitchen. They play together, J.G. tries continuously to be in charge of the game.

In the kitchen, when the game begins with the other child, we notice that he is nervous, trying to keep the toys to himself all the time. He uses verbal language to control the situation and says phrases like „Look Á., this is a sausage. I'm going to put it here. Don't touch it”.

\section{FRIDAY}

SITUATION: We played supermarket games in the usual classroom.

J.G. doesn't cry or scream and he doesn't need to go to the bathroom to calm down.

The game in the classroom develops naturally. J.G. wants the toys from the other children and tends to go and take them off them. When the other child says „No", J.G. stops, and looks at the teacher. The teacher intervenes and takes advantage of his receptive attitude, by adding a new saying: ask him, can you lend it to me? This time the other children agree to lend their materials and asks J.G. to find another one to give them. He does it with pleasure and the game continues calmly.

J.G. accepts the new guideline and participates in the inter changing modelling game calmly. 


\section{MONDAY}

SITUATION: Playing in the playground. There are new motorbikes and everyone wants to use them. J.G. is set on one and only wants that one to play with. When J.G. gets off the bike to get another toy, one of the other children takes the bike.

When the other child takes the motorbike, J.G. lets go of the toy that he has and goes and chases the other child who has the bike screaming and crying. A teacher calls him and tells him to share and now it's the other ones turn to play with the bike. J.G. runs to the bathroom, cries and screams and comes out again to play. He doesn't play with anything or anyone, but he is calm in the playground observing how the other children play.

He doesn't play with anyone in the playground.

When leaving the bathroom, he is calm and he doesn't repeat this behaviour.

\section{TUESDAY}

SITUATION: On Monday the teacher had an interview with the parents. They were informed of the action plan that was being carried out and wanted to be involved in planning certain activities to work on at home: cooperative structure „the suitcase”, sit down to play with it behaving as if they were other children of the same age and invite some friends home to play.

J.G. arrives at school with a suitcase full of his favourite toys. He brought his slippers, books, puzzles and the doll he sleeps with. The family helped with the activity by telling him that when he arrives at school, he will show it all to his classmates and then share it with them. J.G. arrives very excited. He shows what he has brought in and watches out to make sure that nobody takes anything. The teacher reinforces this need to look after his things and tells the children that they can't touch them. The following day goes smoothly and the things remain exposed on a shelf. As the day goes by, J.G. relaxes and then the teacher invites him to share his things. J.G. starts to give each child one of his things. He is anxious when someone takes something that he has given to another child, but little by little he relaxes and everyone is able to play together in which J.G. is included.

J.G. establishes conversations with the other children in which he shows them how to play and tells them everything he knows.

Overcoming the first moment, J.G. then shares his things in a natural way.

\section{WEDNESDAY}

SITUATION: Whilst working in corners in the classroom, the children are invited to play a game of dominoes with different images. J.G participates.

J.G. wants to play with the dominoes and picks up too many pieces. The other children intervene in the game and take pieces that are within their reach. J.G. doesn't cry and he doesn't scream, he goes to the bathroom he leans against the wall and then he comes out of the bathroom again to continue his game calmly. 
During the game, J.G. speaks with other children and starts a conversation in which he asks them to place the pieces in a certain way, he shows the teacher that the pieces are the same, etc.

J.G. shares the material.

\section{THURSDAY}

SITUATION: We celebrate the Canary Island Day party and we do a cooking activity in which the children share the food and prepare a recipe together.

J.G. participate in the activity normally, there are no conflicts.

The focus on the activity is great, there is hardly any conversation between the children. It is obvious that the activity is parallel.

The children share the material, although not intentionally. It is there and they use it, but there is no awareness of sharing it.

\section{FRIDAY}

\section{J.G DID NOT ATTEND THE CLASS}

Observations: During the party, the mother of one of the children in J.G.'s class asked me if we were working on "sharing" in the classroom. She told me that she usually has problems in the park with this, but that two days ago, I., had an invitation to go to the park and she said yes, he could go but told him that he had to share. She took some toys and spent a nice, quiet afternoon in the park. The mother said that she didn't remember an afternoon quite so quiet in the park. There were no fights and I had no problems sharing the toys that he had taken with other children.

Although the action plan has been developed for J.G., tackling the problem in the classroom had made the rest of the children participate in a natural way and take what they done in the classroom into different situations outside of school.

Chart 5: $3^{\text {rd }}$ Week

\section{MONDAY/TUESDAY}

\section{BANK HOLIDAY}

\section{WEDNESDAY}

SITUATION: The children were distributed into teams to perform a task in which they had to colour in the clothes of the class's mascot. The teacher gives a different coloured crayon to each member of the team and says to them: "to change the colour you have to ask your friend for it nicely (the prosocial behaviour of kindness has been worked on with the group during the last three months), "Can you change it with me?" 


\section{WEDNESDAY}

J.G. participates in the activity normally. This change, for children, in this activity is more of a game than an intention to colour in the picture. Some members of J.G.'s team start asking to change their crayons. None of them get to change with J.G. They all continue colouring until after a few seconds a girl tries again and asks J.G. and this time he agrees. They change the crayon and the girl, before she colours again, she asks him to change with her. J.G. says no, but he also answers by saying "First colour in Nico and then we can change". The girl does what he says and then asks him again to change. J.G. does this. He doesn't cry or have any tantrums.

J.G. finally participates in the activity communicating with the other children, in a cordial and conciliatory tone.

J.G. shares his crayons with several of the other children.

\section{THURSDAY}

SITUATION: We begin the class by performing the activity "circle of friends". After singing the song and talking a little about the things that the children took out, we rolled the "happy dice" and the "share" face came out. We say aloud phrases that help us share and the children come out with ... "One for you, one for me", "Can you change it?" "Let's share". The teacher supports these phrases in real situations that have occurred or could occur in the classroom. The classroom is prepared with corners to practice "play and share".

J.G. moves freely in the corners. The train is what catches his attention most. There are 15 students and there are only 4 trains to play with. J.G. wants the trains but the other children have them. He asks them if he can borrow them. The other children don't want to, so J.G. takes something else to play with. He doesn't cry and doesn't need to go to the bathroom to calm down.

Whilst passing around the corners, he is calm, talks with his companions and becomes part of the other children's game. He demonstrates an attitude where he can direct the game.

He shares the material and asks to borrow material from the other children verbally. He doesn't take the toys and shares some of what he has.

\section{FRIDAY}

SITUATION: We received an email from J.G.'s parents

Hello Sandra:

I am writing to tell you how it went with the activities you told us to do at home to correct J.G.'s behaviour:

1) We played with J.G. as if we were children. This was the first activity we did and we want to tell you that, as a result, J.G. allowed us to play with him but he wanted to control the game at all times.

2) He played with a friend at home. Initially they fought because J.G. didn't want to give him his toys but as the afternoon progressed, he began to share his toys and they even played together. 
On Wednesday, we went to the park and I took some chalks for them with the aim that he would be forced to share them. I took them all out and told him that they were for him to play with the children.

At first, he got angry because the children came and took the chalks, but I explained to him that if they asked him for permission, he had to share the chalks and he did.

I have seen that when he goes to the park he begins to play with other children and he no longer closes up. So, thank you very much for the advice Sandra.

Have a good weekend!

\section{Chart 6: Conclusions}

\begin{tabular}{|c|c|c|c|}
\hline & V1 & $\mathbf{V} 2$ & V3 \\
\hline \multirow[t]{2}{*}{$1^{\mathrm{a}}$ week } & $\begin{array}{l}\text { The tantrums } \\
\text { decreased in } \\
\text { their duration } \\
\text { and intensity as } \\
\text { the week went } \\
\text { by. }\end{array}$ & \multirow{2}{*}{$\begin{array}{l}\text { Once he managed to } \\
\text { overcome the crying, } \\
\text { he was able to start } \\
\text { a conversation that led } \\
\text { him to enjoy the game } \\
\text { in the company of the } \\
\text { others. }\end{array}$} & \multirow{2}{*}{$\begin{array}{l}\text { At the end of the week, } \\
\text { he enjoyed the game, } \\
\text { beginning small inter } \\
\text { changes. }\end{array}$} \\
\hline & $\begin{array}{l}\text { The "time out" } \\
\text { served to calm } \\
\text { him down and } \\
\text { face the situation } \\
\text { more calmly. }\end{array}$ & & \\
\hline $2^{\mathrm{a}}$ week & $\begin{array}{l}\text { The time out is } \\
\text { automatic and } \\
\text { begins to be } \\
\text { a substitute for } \\
\text { tantrums. }\end{array}$ & $\begin{array}{l}\text { The conversation with } \\
\text { the other children gets } \\
\text { better each time during } \\
\text { the activities. These } \\
\text { conversations help him } \\
\text { to control the situation } \\
\text { and he is able to guide } \\
\text { the other children to } \\
\text { take the first steps in } \\
\text { a cooperative game. }\end{array}$ & $\begin{array}{l}\text { He finds it difficult to } \\
\text { give up the material he } \\
\text { has in his possession. }\end{array}$ \\
\hline $3^{\mathrm{a}}$ week & $\begin{array}{l}\text { There is no out } \\
\text { of control crying } \\
\text { behaviour. } \\
\text { His attitude is } \\
\text { calmer and he } \\
\text { doesn't need } \\
\text { to use time out } \\
\text { to modify the } \\
\text { situation. }\end{array}$ & $\begin{array}{l}\text { The conversation } \\
\text { becomes evident in the } \\
\text { game with the other } \\
\text { children. This decreases } \\
\text { the degree of anxiety } \\
\text { that is generated when } \\
\text { the other children come } \\
\text { and take the toys. }\end{array}$ & $\begin{array}{l}\text { He shares the material } \\
\text { and the toys most } \\
\text { of the time. When he } \\
\text { doesn't, he accepts the } \\
\text { teacher's invitation and } \\
\text { modify his decision } \\
\text { easily. }\end{array}$ \\
\hline
\end{tabular}




\begin{tabular}{|l|l|l|}
\hline V1 & \multicolumn{1}{|c|}{ V2 } & \multicolumn{1}{|c|}{ V3 } \\
\hline H1 & H2 & $\begin{array}{l}\text { The frustration that causes the child to have a lack } \\
\text { of understanding of other perspectives different } \\
\text { from his own, is something natural. An adequate } \\
\text { education project will help him to change his } \\
\text { attitude and be more flexible to change. }\end{array}$ \\
\cline { 2 - 4 } CONCLUSIONS & $\begin{array}{l}\text { The support of the other children is indispensable. } \\
\text { When learning is carried out from a single vertical } \\
\text { perspective (adult-child), it loses the spontaneity } \\
\text { that the natural context of the child provides: its } \\
\text { equals. Cooperative Learning offers successful } \\
\text { techniques that are the basis of learning that are } \\
\text { based on modelling and role playing, these give } \\
\text { the first signs of reciprocity among the children. }\end{array}$ \\
\cline { 2 - 4 } & H3 & $\begin{array}{l}\text { A shared education between family and school } \\
\text { is fundamental. At an early age learning is } \\
\text { established best in everyday life experiences. } \\
\text { To ensure that the child changes new learning } \\
\text { abilities to different situations, the collaboration } \\
\text { of the family is fundamental. The coherence } \\
\text { between both environments will offer the child } \\
\text { a deeper knowledge and advancement that will } \\
\text { provide the child with the necessary security to } \\
\text { successfully achieve the planned objective. }\end{array}$ \\
\hline
\end{tabular}

\section{References}

Bedoya Rodriquez, Ana Esther. Del liderazgo transformacional al liderazgo prosocial: Evidencias obtenidas en la Dirección de organizaciones sanitarias catalanas. Bellaterra: Universidad Autónoma de Barcelona, 2015.

Caprara, Gian Vittorio, Guido Alessandri, Nancy Eisenberg. "Prosociality: The Contribution of Traits, Values, and Self-Efficacy Beliefs". Journal of Personality and Social Psychology 6/102 (2012): 1289-1303. doi: 10.1037/a0025626.

Cirera Amores, Maria Carme. Estudio cualitativo del liderazgo prosocial: El Proyecto SPRING. Bellaterra: Universidad Autónoma de Barcelona, 2015.

Escotorín, Soza, Gloria Pilar, Robert Roche. Cómo y por qué prosocializar la atención sanitaria: reflexiones, desafios y propuestas. La Garriga: Fundación Martì L'Humà, 2011.

Escotorín, Soza, Gloria Pilar. Comunicación interpersonal de calidad prosocial: hacia una definición del concepto y síntesis teórica actualizada del modelo 
aplicable a díadas en contextos organizacionales. Bellaterra: Universidad Autónoma de Barcelona, 2008.

Escotorín, Soza, Gloria Pilar. Prosocial Communication Inquiry in collaboration with gerontology health professionals. Consulta sobre comunicación prosocial con profesionales socio-sanitarios del ámbito gerontológico. Bellaterra: Universidad Autonoma de Barcelona, 2013.

Lencz, Ladislav. "The Slovak Ethical Education Project". Cambridge Journal of Education 3/24 (1994): 443-451.

Luengo Kanacri, Bernadette P., Concetta Pastorelli, Nancy Eisenberg, Antonio Zuffianò, Gian Vittorio Caprara. "The Development of Prosociality from Adolescence to Early Adulthood: The Role of Effortful Control". Journal of Personality and Social Psychology 3/81 (2013): 302-312. https://doi.org/10.1111/ /jopy. 12001.

McGinnis, Ellen, Arnold Goldstein. "Programa de Habilidades para la Infancia Temprana". http://www.oei.es/historico/inicial/articulos/habilidades_infancia.pdf [access: 20.02.2018].

Musse, Paul, Nancy Eisenberg. The Roots of Caring, Sharing, and Helping: The Development of Pro-Social Behavior in Children. San Francisco: W. H. Freeman, Nation at Risk, 1977.

Robert, Roche. Hacia una teoria de prosocialidad Lipa. Barcelona: Universidad Autonoma de Barcelona, 2014.

Roche, Robert, Esther Arozarena. "Algunas dimensiones de la comunicación de calidad en la pareja". Actas de las IX Jornadas Españolas de Terapia Familiar 18 (1988): 425-445.

Roche, Robert, Reinaldo Martínez-Fernández. "Efectos de un programa de entrenamiento prosocial en la comunicación de pareja". Revista de Tarapia Sexual y de Pareja 24 (2006): 30-50.

Roche, Robert. "Violencia y Prosocialidad: un programa para y descondicionamiento frente a la violencia en la imagen y para la educación de los comportamientos prosociales". In: Que Miras?, 291-313. Valencia: Publicaciones de la Generalitat Valenciana, 1991.

Roche, Robert. "Comunicación de calidad en la pareja y en las relaciones interpersonales". Familia y Sociedad 1 (1994): 363-367.

Roche, Robert. "L'educazione alla prosocialità come ottimizzatrice della salute mentale e della à nelle relazioni sociali". Nuova Umanità 21/121 (1999): 29-48.

Roche, Robert. Educacion Prosocial de las emociones, valores y actitudes positivas para adolescentes en entornos familiares y escolares. Barcelona: Blumes, 1998.

Roche, Robert. Eticka vychova. Bratislava: Orbis Pictus Istropolitana, 1992. 
Roche, Robert. Inteligencia prosocial: educación de las emociones y valores. Cataluña: Servei de Publicacions Universitat Autònoma de Barcelona, 2004.

Roche, Robert. L'intelligenza prosociale. Trento: Erikson, 2002.

Roche, Robert. Prosocialidad: Nuevos desafios. Metodologías y pautas para una optimización creativa del entorno. Buenos Aires: Ciudad Nueva, 2010.

Roche, Robert. Psicología de la Pareja y de la Familia Analisis y Optimización. Bellaterra: Servei de Publicacions Universitat Autònoma de Barcelona, 2006.

Roche, Robert. Psicología y Educación para la Prosocialidad. Barcelona: Universitat Autònoma de Barcelona, 1995.

Roche, Robert. Psicología y Educación para la prosocialidad. Buenos Aires: Ciudad Nueva, 1997. 